\title{
Conclusion and Recommendations
}

Lawyers tend to agree that as an empirical matter, domestic courts increasingly often apply international law. The Swiss Federal Tribunal, for instance, is more frequently confronted with this body of law today than in the past, judging from the growing number of references to it in its practice. As I have shown elsewhere, the percentage of rulings of the Swiss Federal Tribunal mentioning international law has more than tripled between 1954 and 2014. ${ }^{2001}$

When domestic courts apply international law - which does not concern all cases in which international law is mentioned - they are required to determine its meaning and, hence, to interpret it. Yet as I have highlighted in this book, domestic judges across the world, including Swiss courts, tend to neglect the interpretative methods required by international law, ie, textual, systematic, teleological, and historical interpretation. Moreover, domestic courts often fail to meet the standards of good judicial reasoning to which both domestic and international law aspire, ie, predictability, clarity, and consistency.

In this book, I have argued why States and their courts must take the interpretative methods of international law more seriously. I have shown that States must do so regardless of their domestic (and especially their constitutional) legal specificities, and that courts must do so irrespective of the outcome of their decisions. I have also stressed that States and their courts can and must do better in terms of reasoning. Courts in particular must strive to provide interpretations of international law that live up to the virtues of high-quality judicial reasoning, ie, predictability, clarity, and consistency. These virtues are not necessarily legal requirements, but our laws and legal practices aspire to fulfill them. Said virtues are used in both domestic and international legal practice to evaluate the quality of interpretations and the degree to which a given decision should influence future interpretations of the law. Importantly, these three virtues serve legality. Disrespecting them means promoting opacity and, thereby, facilitating departures from what the law requires.

2001 Ammann, 'International Law in Domestic Courts Through an Empirical Lens: The Swiss Federal Tribunal's Practice of International Law in Figures' ( $\left.n_{5}\right)$.

(C) ODILE AMMANN, 2020 | DOI:10.1163/9789004409873_011

This is an open access chapter distributed under the terms of the CC-BY-NC 4.0 Licensei le Ammann - 9789004409873 
Interpretation is an activity that is both free and constrained, and judicial interpretation is no exception (supra, Chapter 2). Judicial creativity, in order to respect the law, must respect the frame traced by the law, a frame that includes the law's interpretative methods. Legal interpretation is governed by methods which sometimes also exist in codified form, namely textual, systematic, purposive, and historical interpretation (supra, Chapter 6). These methods are customary in domestic and international law. The law's interpretative methods must be obeyed even if they do not determine the interpretative outcome, and even if their neglect does not always trigger a violation of States' international legal obligations. It is worth noting that the law's interpretative methods do not challenge the maxim jura novit curia. Instead, they ensure that the law that courts are called to identify is respected.

Both interpretative methods and the virtues of high-quality judicial reasoning may overlap with other legal duties, such as judges' domestic duty to provide reasons for their decisions, or States' duty to interpret treaties in good faith. They may also intersect with other legal and moral principles that apply to judicial interpretation, and especially with the principle of the rule of law, which is both a moral and a legal principle. While these various principles and the questions they raise are undoubtedly important for the activity of domestic courts, their analysis is beyond the scope of this project and must be left for another occasion.

In this book, I have clarified the legal effect of domestic rulings in international law (supra, Chapter 4). Bringing the domestic judicial practice of international law in conformity with the law's interpretative methods and with the virtues of predictability, clarity, and consistency matters not only because States must respect international law. It also matters because domestic judicial decisions can contribute to the formation and evolution of international law (art. 38(1)(a)-(c) ICJ Statute), and because they can assist interpreters in ascertaining international law (art. 38(1)(d) ICJ Statute). It is therefore important that domestic rulings actually establish what they are meant to establish, from the perspective of both their legality and quality.

I have also explained why there are good reasons for constraining States (including their courts) in their interpretations of international law (supra, Chapter 5). I have identified three main reasons for doing so. First, the frequent vagueness of international law can lead to arbitrariness if there is no legal framework to harness it. Second, in liberal democracies, judges must be accountable to the lawmaker. Third, international law is governed by the principle of auto-interpretation, ie, the principle that every State has the power to interpret its international obligations for itself when no international 
court is competent to do so. This power leaves room for self-serving interpretations, and this risk must be mitigated if States are to interact on a level playing field.

I have then described the interpretative methods required by international law in more detail, and I have explained why there are good reasons for using these methods (supra, Chapter 6). In this context, I have highlighted the similarity of interpretative methods in domestic and international law, even if the respective characteristics of domestic and international lawmaking can lead to differences in the way these methods are used. This similarity should make courts less skeptical or neglectful of international methods. It should show them that the basic interpretative tools which international law requires States to use are familiar ones. Importantly, these tools must be used and be taken seriously with regard to both domestic and international law.

Finally, I have analyzed the Swiss case law on international law to determine whether it observes said methods and virtues of judicial reasoning. A study of the Swiss judicial practice pertaining to treaty law (supra, Chapter 7), customary international law, and general principles of international law (supra, Chapter 8) reveals that there is room for improvement from the perspective of the law's interpretative methods, on the one hand, and of highquality judicial reasoning, on the other hand. I have highlighted four clusters of difficulties that apply to all three sources of international law under scrutiny: (i) courts' disregard or misapplication of the interpretative methods of international law; (ii) the lack of substantiation of courts' interpretative assertions (and, relatedly, their reliance on auxiliary means like scholarship, but not on more direct expressions of State practice); (iii) the self-referentiality and even circularity of the case law (as courts primarily rely on the practice of their own State, on their own case law, and on domestic scholarship, as opposed to the practice and scholarship of other States); and finally (iv) the imprecise terminology and uneven level of detail of domestic courts' reasoning on international law, and the frequent superficiality and repetitiveness of this reasoning.

Of course, not every application of international law raises difficult interpretative issues. In such cases, judges cannot be expected to discuss international legal issues at length. Moreover, judges are constrained in terms of the resources they can resort to. Judicial economy, in particular, requires them to dispose of cases efficiently. These constraints must be factored in when formulating recommendations for improving the practice (infra, section 2). However, they are not compelling justifications for leaving things unchanged. 


\section{Recommendations}

The current Swiss judicial practice of international law shows that both the legality and the quality of Swiss rulings need to be improved (infra, 2.1). Moreover, given the status of domestic rulings in the sources of international law and as auxiliary means, their accessibility needs to be enhanced (infra, 2.2).

I address each of these points in turn, and formulate recommendations on how these goals can be met. While I do not go into the details of the specific organizational measures that would be required within the courts (and beyond) to improve the practice, the recommendations listed below point to the direction in which reforms should go.

\subsection{Improving the Legality and the Quality of Domestic Rulings}

Domestic judicial decisions are not reliable elements of determination of the sources of international law, nor are they reliable auxiliary means to determine the meaning of international law, if they have not been reached in conformity with international law. The same applies to decisions that do not offer predictable, clear, and consistent interpretations of international law. If compliance with international law, its methods, and high-quality judicial reasoning is to be achieved, courts must address and remedy the four clusters of problems identified in this book (supra, section 1).

Taking these problems seriously necessitates allocating adequate resources to international legal issues. It also requires deeper institutional reforms. Two major ways of improving the Swiss judicial practice deserve emphasis. They pertain to domestic courts' level of expertise on international law (infra, 2.1), but also to specific institutional measures that can strengthen the legality and the quality of their reasoning (infra, 2.2).

Before discussing these two points, it is important to acknowledge that the obvious need for efficiency precludes judges from engaging in a full-fledged and textbook-like study of State practice whenever a case touches upon an issue of international law. Nor can we reasonably demand from judges to keep track of all foreign and international case law. Human knowledge about the practice of international law is, by definition, imperfect. On a practical - and important - level, both time and money are, as we all know, finite resources. Thus, when international law is only mentioned in passing without influencing the court's reasoning, or when its meaning is uncontroversial or has been clarified extensively in previous cases, judicial economy and common sense explain why judges do not provide detailed reasoning.

However, there is a fine line between practical (but also rule-of-law-type) concerns about judicial economy, and a systematic, troubling neglect of 
legality and quality in judicial decision-making. When ascertaining international law, obvious interpretative mistakes must be avoided, such as the use of domestic travaux préparatoires to interpret a treaty, or the neglect of a coherent, constant, and general State practice in the context of CIL. Moreover, high-quality reasoning is arguably just as important as judicial economy. A first step that must be taken to achieve these goals is to strengthen domestic courts' expertise in the field of international law.

\subsubsection{Strengthening Courts' Expertise on International Law}

To ensure that Swiss courts respect international law and its interpretative methods, and for their rulings to constitute reliable auxiliary means, Swiss courts' expertise on international law needs to be strengthened. Judges with in-depth knowledge of international law should be allocated to chambers in which international legal issues are particularly likely to arise. ${ }^{2002}$ Moreover, to analyze international legal issues, judges must be able to collaborate with specialized judicial staff (eg law clerks) ${ }^{2003}$ with adequate linguistic and substantive legal skills. Importantly, courts must be able to access a pool of experts within their institution, instead of having to reach out to other domestic authorities. For instance, if Swiss courts consult the Swiss Directorate of International Law and, therefore, the federal executive, their independence may be undermined.

Another important measure that must be taken is to improve the access of courts and their staff to international legal materials and to specialized documentation. This includes platforms such as ILDC and the International Law Reports, which provide summaries of relevant domestic judgments on international law, but also other online databases that grant extensive access to specialized scholarly literature. In this context, it is essential that domestic courts are exposed to a broad range of legal materials that reflects the diversity of national approaches to international law. Access to foreign scholarship, and especially to non-Western scholarship not originally written in English, or not translated into English, is still limited and must clearly be improved. The same applies to the case law of foreign courts: both the ILDC database and the International Law Reports are biased towards Western, English-speaking States. Given domestic courts' prominent place from the perspective of art. 38 ICJ Statute (supra, Chapter 4, section 3), an overrepresentation of some States in

2002 On this point, see Bucher (n 264) para 48.

2003 On this topic, see Peter Bieri, 'Law Clerks in Switzerland: A Solution to Cope With the Caseload?' (2016) 7 International Journal of Court Administration 29. 
widely used databases means that the practice of these States will be inflated on the international plane.

Specialized training on Switzerland's international obligations and other important topics of international law should be available and even become mandatory for Swiss judges and their staff. ${ }^{2004}$ For instance, it has been shown that some treaties ratified by Switzerland are not well-known by the courts. ${ }^{2005}$ Swiss courts should also be informed in a regular and systematic fashion about important domestic and foreign cases on international law. Reading up on these topics cannot be left to the initiative of individual judges and law clerks. Instead, institutional incentives are needed.

Yet another way of strengthening domestic courts' expertise and awareness of international legal issues is for judges to foster regular intellectual exchanges with other domestic and foreign judiciaries. Such interactions allow domestic judges to share their knowledge and difficulties, and to discuss cross-cutting international legal issues. While such exchange platforms already exist, they must be used more fruitfully for discussions pertaining to international law specifically. ${ }^{2006}$

It is important to stress that the aim of such measures is not to foster hermeneutic uniformity, in the sense that courts in all States would have to reach the same interpretative conclusion when facing a given international legal issue. This is not what I am arguing for, nor is this what international law and the VCLT require from States. However, domestic courts in all States must respect the sources and interpretative methods of international law. This also means that they must interpret international law with due regard for foreign judicial practices, which contribute to the formation and evolution of international law. Moreover, qua auxiliary means, foreign rulings can facilitate domestic judges' interpretative task. If domestic judicial decisions are to contribute to international lawmaking, they must be known to courts in other States.

It is worth noting that advocacy plays an important part in improving domestic courts' expertise on international legal issues. In most cases, lawyers are the ones who raise such issues in the first place, and the contribution their briefs make to the reasoning of domestic courts cannot be underestimated. Skilled advocates with an in-depth knowledge of international law greatly strengthen

2004 For a similar point, see Bucher (n 264) para 49.

2005 This need has for instance been highlighted by the CEDAw Committee: Concluding Observations of the CEDAW Committee, Un Doc CEDAW/C/CHE/Co/3/7, 7 August 20o9, para 16.

2006 One example and potential model, in this context, is the Network of the Presidents of the Supreme Judicial Courts of the European Union. See $<$ reseau-presidents.eu/fr/cpcl $>$. 
the legality and quality of judicial decision-making. Domestic courts' expertise in the field of international law can only benefit from lawyers who are trained accordingly and who regularly practice in this field.

In Switzerland, international law does not have a prominent place in advocacy. The great bulk of Swiss law firms do not specialize in public international law, even if a handful of them have developed expertise in this area. One possible explanation for this is that international law is not a formal requirement to pass the bar exam in Switzerland. Moreover, the Swiss legal market is relatively small, so it might not seem worthwhile for law firms - especially for smaller ones - to develop a strong focus on international law.

The lack of emphasis on international law in legal practice, but also in law schools (infra), means that lawyers may not always recognize the international law dimensions of their clients' cases. Even when they do, the low profile of international law may lead them to think that invoking international law is unlikely to be successful and that this strategy might even harm their case. Moreover, there is no culture of pro bono litigation in Switzerland, and litigation is costly. Thus, many individuals and small or midsized businesses will be discouraged from going to court for financial reasons. As courts can only interpret international law if a corresponding case is brought to them, it can be expected that many questions pertaining to international law will never make it to the courtroom. Thus, for courts' international law expertise to be strengthened, the legal profession must place greater emphasis on, and invest in, international law. In the meantime, it is essential that prominent cases in which international legal issues are raised are well argued. Through the intellectual rigor of their briefs, lawyers can have a significant impact on the Swiss judicial practice and beyond.

One such example of a remarkably well argued, high-profile case is the 'KlimaSeniorinnen' litigation. In this case, the association 'KlimaSeniorinnen Schweiz' (which seeks to ensure that elderly women are protected from the effects of climate change) and four other women argued in great detail that the Swiss government's failure to properly address climate change by taking effective measures for the prompt reduction of $\mathrm{CO}_{2}$ emissions violated various constitutional rights as well as international human rights law, including art. 2 and 8 ECHR. They also invoked art. 6(1) and 13 ECHR, and mentioned art. 34 EC HR. ${ }^{2007}$ After the Federal Department of the Environment, Transport, Energy, and Communications (DETEC) declared their - thoroughly and carefully

2007 The full argumentation is available at <ainees-climat.ch/documents>. 
reasoned - application inadmissible, ${ }^{2008}$ the KlimaSeniorinnen appealed to the SFAC. The Court rejected the appeal in a brief judgment that hardly engaged with the international legal issues at stake. ${ }^{2009}$ At the time of writing (June 2019), the - again, extremely thorough - appeal of the KlimaSeniorinnen before the Swiss Federal Tribunal was still pending. ${ }^{2010}$ The extent to which the Court will engage with the appellants' claims pertaining to international law remains to be seen.

Another important way of fostering domestic expertise is through law teaching. ${ }^{2011}$ Currently, public international law is, for many law students in Switzerland, a one-time occurrence in the curriculum, usually in the form of a mandatory module at the beginning of their studies. While other law courses sporadically include references to international law (eg to the ECHR), occasional mentions alongside domestic law do not not suffice to strengthen students' international law expertise. Moreover, there is little clinical education and training for advocacy skills at law schools, including in public international law. Only a minority of law graduates will choose to deepen their basic knowledge of public international law through research and practical experience at a later point. Thus, the fact that international law does not figure more prominently in legal briefs and domestic court rulings should not come as a surprise. If higher education institutions - and those training and testing future advocates - put greater emphasis on international law, the domestic practice pertaining to international law can only stand to gain in richness and depth.

Of course, and as I will emphasize (infra, 2.2), initiatives are also needed at the international level to strengthen domestic courts' expertise on international law.

2008 DETEC, decision of 25 April 2017, available at <ainees-climat.ch/documents $>$. The DETEC found that the authorities' alleged failure to take appropriate measures against climate change did not affect the appellants' rights and obligations, and that they could therefore not request a ruling on real acts as per art. 25a of the Federal Act on Administrative Procedure of 20 December 1968 (SR 172.021). The DETEC further held that the applicants did not have victim status, and that they could therefore not enjoy the protection of art. 13 ECHR.

2009 SFAC, judgment A-2992/2017 of 27 November 2018. Only paragraph 8 engages with international law, namely with art. 6(1), 13, and $34 \mathrm{ECHR}$, and not with art. 2 and 8 ECHR.

2010 The appellants' brief is available at <ainees-climat.ch/documents $>$.

2011 For a historical analysis of international law teaching in Switzerland, see Andreas R Ziegler, 'Die Entwicklung der Völkerrechtslehre und -wissenschaft in der Schweiz: Eine Übersicht' (2016) 26 Swiss Review of International and European Law 1. 


\subsubsection{Addressing Institutional Obstacles}

Several more profound reforms can help support the legality and quality of Swiss rulings pertaining to international law. Indeed, various features of the Swiss legal order (supra, Chapter 3) constrain Swiss courts' interpretative activity in a way that can be problematic from the perspective of these two vantage points.

The political affiliation of most Swiss judges (which includes an annual fee to their political party), and the fact that judges must stand for reelection, are ways to address a legitimate, deep-rooted concern of the Swiss polity to secure judges' democratic accountability. However, these constraints can be problematic from the perspective of judicial independence. Consequently, they can jeopardize the legality and quality of judicial reasoning. This difficulty with regard to judicial independence is particularly salient in international law, which is heavily politicized. In Switzerland, some political groups frequently target specific areas of international law, such as international refugee law, IHRL and the case law of the ECtHR, Swiss-E U relationships, and the relationship between domestic and international law (supra, Chapter 3, 3.4). While debating international law domestically is not only legitimate, but essential, the politicization of international law increases the pressure on Swiss judges. Importantly, the institutional constraints to which they are subject may negatively influence the legality and quality of their work.

Separate opinions are worth exploring for the Swiss judiciary, at least for the Swiss Federal Tribunal (supra, Chapter 3, 4.2.5). They foster judges' thorough, comprehensive, and transparent engagement with international legal issues, which serves both the quality and the legality of judicial decisions. Of course, judges are more likely to deliver separate opinions if the political pressures they face are acknowledged and addressed. Moreover, introducing separate opinions further increases judges' already heavy workload. Still, they can significantly improve the sharpness of the domestic case law.

Finally, Swiss courts' so-called 'pragmatic methodological pluralism' has obvious advantages: it encourages interpretative solutions that are adapted to the case at hand. Yet this methodological framework cannot gloss over the characteristics of international lawmaking, nor can it be used by courts to justify a lack of predictability, clarity, and consistency. Courts cannot apply it to international legal issues without the necessary adjustments. For instance, they must acknowledge that historical interpretation requires looking at the practice of the treaty parties, and not merely at the practice of their own State. Pragmatic methodological pluralism must remain a flexible tool, but it should not become an alibi. 


\subsection{Enhancing the Accessibility of Domestic Rulings}

After having suggested ways of improving the legality and the quality of Swiss rulings (supra, 2.1), I now turn to more general measures that need to be taken with regard to domestic rulings, considering their place in the sources of international law.

Given that domestic judicial decisions contribute to the formation and evolution of international law, and considering that they are auxiliary means in international law (supra, Chapter 4, section 3), the availability of these judgments needs to be enhanced. ${ }^{2012}$ Indeed, if domestic rulings are hard to access, they cannot (and, from a rule of law perspective, should not) contribute to the formation and evolution of international law. Nor can (and should) such rulings deploy their effects qua auxiliary means, by assisting interpreters in the ascertainment of international law.

Some Swiss rulings that are relevant from the perspective of international law are difficult for foreign judges and legal scholars to identify and/or read, and there are hardly any comprehensive syntheses of the Swiss case law on international law. The searchability of this case law needs to be improved. Important decisions should be broadly available (even if only in the form of a summary) and systematically included in relevant databases, such as the ILDC database and the International Law Reports.

Beyond Switzerland, and as I have previously noted (supra, 2.1.1), access to the case law of non-English speaking (but also non-Western) jurisdictions is still limited. ${ }^{2013}$ As a result, and for a variety of reasons that cannot be fully unpacked here, there is an imbalanced and selective use of domestic rulings in international legal practice and scholarship. Recent research ${ }^{2014}$ as well as the

2012 This point is in line with previous efforts to make State practice more broadly available, eg Council of Europe, Committee of Ministers, Recommendation No R (64) 10 on the Publication of Digests of State Practice in the Field of Public International Law, 6 October 1964, <www.coe.int/t/dlapil/cahdi/Source/Texts_\&_Documents/ Resolution_64_10_en.pdf>; Recommendation No R (97) 11 on the Amended Model Plan for the Classification of Documents Concerning State Practice in the Field of Public International Law, 12 June 1997, <www.coe.int/t/dlapil/cahdi/Source/Texts_\&_ Documents/Recommendation_97_11_en.pdf>. See also ILC, 'Report on the Sixty-Eighth Session (2 May-10 June and 4 July-12 August 2016)' (n 904) para 54 ff; ILC Secretariat, 'Formation and Evidence of Customary International Law, Elements in the Previous Work of the International Law Commission That Could Be Particularly Relevant to the Topic' (2013) Un Doc A/CN.4/659; Forteau (n 280).

2013 TWAIL scholars have flagged that the practice of non-Western States is neglected, see eg (in the context of CIL) Chimni (n 1193) $20 \mathrm{ff}$.

2014 Roberts, Is International Law International? (n 9) 166-172. 
ILDC casebook published in $2018^{2015}$ confirm this anglophone (and, more generally, Western) bias. This imbalance is highly problematic from the perspective of State's equal place in the sources of international law and as international lawmakers. The practice of non-Western legal systems in particular needs to be more easily accessible to the average domestic decision-maker and scholar, eg via domestic digests on States' international legal practice. ${ }^{2016}$ Important decisions should not merely be available in English, since many domestic judges do not routinely consult resources in this language. The domestic case law included in relevant databases needs to be regularly updated based on consistent criteria, and in a geographically balanced way. Such databases must offer a truly inclusive, representative, and reliable picture of the domestic judicial practice of international law.

Taking such measures is important because databases like ILDC and the International Law Reports are widely used by international legal scholars. While some researchers may acknowledge the potential limitations of such tools, they will, in most cases, and for lack of a better option, still choose to base their work on them. ${ }^{2017}$ Databases should also include lower court cases. Importantly, this case law must be accessible to all, and not restricted to a narrow circle of research institutions, as is currently the case with ILDC and the International Law Reports. From the very beginning, the goal of the ILDC database has been to make relevant domestic case law 'more accessible to a larger audience.2018 Similar remarks apply to the International Law Reports, which are only accessible to scholars affiliated to specific research institutions, yet purport to have an unparalleled 'authoritative position in international law'. 2019

The (undoubtedly ambitious) task of increasing the visibility of domestic case law could be entrusted to the UN's Office of Legal Affairs. This would turn

2015 The most cited jurisdictions include Canada, Germany, Italy, the United Kingdom, and the United States. See Nollkaemper and Reinisch (n 89) xiii ff.

2016 As of 1 October 2017, only 30 States were publishing such domestic digests, see ILC Secretariat, 'Identification of Customary International Law: Ways of Making the Evidence of Customary International Law More Readily Available' (n 1328) 35 para 105. The digest of the Swiss practice pertaining to international law, currently compiled by Lucius Caflisch, is published yearly in the Swiss Review of International and European Law.

2017 See eg Ryngaert and Hora Siccama (n 229) 4: 'We cannot exclude the existence of other relevant cases that have not been reported in ILDC or ILR. National reporters for these databases may be inactive, or even non-existent, as a result of which domestic cases relevant to customary international law may not have been reported. Whether ILDC or ILR suffer from reporting bias is not part of our inquiry, however'.

2018 Nollkaemper and Reinisch (n 89) iii.

2019 Cambridge Core, International Law Reports, <www.cambridge.org/core/series/ international-law-reports/69 ${ }_{73} \mathrm{E}_{3} 843 \mathrm{D}_{7} \mathrm{OA} 8 \mathrm{CDB}_{15} \mathrm{CFA}_{24351 \mathrm{CC} 27>\text {. }}$ 
such a project into a State-driven and public endeavor. A project conducted under the aegis of the UN would be able to do justice to linguistic diversity, given the linguistic resources and working languages of the organization. When pursuing such a project, the ILC Secretariat's 2019 memorandum on 'Ways and Means for Making the Evidence of Customary International Law More Readily Available 2020 can serve as an important source of inspiration. The memorandum contains helpful remarks about the linguistic and practical obstacles to making State practice available. ${ }^{2021}$ Another useful resource is the working paper on the same issue which Manley O Hudson submitted to the ILC in 1950 in his quality as Special Rapporteur. ${ }^{2022}$ Close to seven decades later, the ILC Secretariat notes that this recommendation to make State practice more broadly available 'has not yet been heeded by most governments'. ${ }^{2023}$ It is worth noting that Hudson even recommended the conclusion of a multilateral agreement 'providing for a comprehensive exchange of Government publications on questions of international law and international relations.'2024 While both Hudson's working paper and the Secretariat's report deal with State practice in relation to CIL, many of the findings and recommendations they contain can also be applied to State practice that is relevant in the context of treaties and general principles, as well as to auxiliary means.

One risk of such measures is data overload. The Swiss Federal Tribunal, for instance, provides full electronic access to all its recent case law. Such a liberal publication policy makes it difficult to identify relevant decisions. Moreover, Manley O Hudson's statement that 'it would be a herculean task to assemble the decisions on questions of international law of the national courts of all States' holds even more true today than when he wrote it in $195{ }^{\circ} .^{2025}$ On the other hand, it would be unfortunate to lose the complexity and richness of domestic judicial practice by including only a limited number of domestic cases in relevant databases. To handle this complexity and the amount of cases, all States should use at least roughly the same criteria of classification when they

2020 ILC Secretariat, 'Identification of Customary International Law: Ways of Making the Evidence of Customary International Law More Readily Available' (n 1328).

2021 See ibid $30 \mathrm{ff}$ para $84 \mathrm{ff}$.

2022 ILC, 'Article 24 of the Statute of the International Law Commission, Working Paper by Manley O Hudson, Special Rapporteur' (1950) UN Doc A/CN.4/16 and Add. 1.

2023 ILC Secretariat, 'Identification of Customary International Law: Ways of Making the Evidence of Customary International Law More Readily Available' (n 1328) 29 para 82.

2024 ILC, 'Article 24 of the Statute of the International Law Commission, Working Paper by Manley O Hudson, Special Rapporteur' (n 2022) 32 para 92.

2025 See ibid 28 para 39. 
publish domestic digests on the practice of international law. ${ }^{2026}$ Such digests are helpful to identify important new cases that need to be added to existing databases. Moreover, they facilitate the use of foreign case law by other domestic courts qua elements of the sources of international law and qua auxiliary means. The Swiss Federal Tribunal and other courts could also communicate the most relevant decisions from the perspective of international law in their annual reports or through press releases. ${ }^{2027}$

Another risk is that international agencies (eg the UN's Office of Legal Affairs) guide the outcome of domestic courts' reasoning about international law, instead of merely offering them methodological assistance. This influence on the result reached by judicial decisions must be avoided. In any case, such a control on interpretative outcomes is not what the present book is calling for. I have argued for a homogeneous hermeneutic framework in international law, but not for a homogeneous case law all things considered.

It goes without saying that the proposed measures cannot be implemented if States and other relevant actors do not devote enough resources to this topic. One must stress that such steps are needed if courts are to fulfill their task as legal interpreters, and if they are to offer reliable means of determination of international law that can be used by other decision-makers, instead of painting a skewed picture of international law.

Of course, whether the picture painted by a domestic court is indeed skewed is a complex question, unless the court is explicit about what it is doing. A court may be contributing to a more broadly supported evolution in the practice of international law. ${ }^{2028}$ It may also simply be expressing reasonable disagreement with other courts, government branches, and States on a given issue. Hence, the weight given to domestic courts' interpretations must necessarily be determined in context, with regard to the specific case.

2026 Recommendation No R (97) 11 on the Amended Model Plan for the Classification of Documents Concerning State Practice in the Field of Public International Law, 12 June 1997, <www.coe.int/t/dlapil/cahdi/Source/Texts_\&_Documents/Recommendation_97_ 11_en.pdf >.

2027 Ehrenzeller (n 638) $19 \mathrm{f}$.

2028 This issue has for example been addressed by Katzenstein, 'International Adjudication and Custom Breaking by Domestic Courts' (2012) 62 Duke Law Journal 671. 